\title{
НАСТАВА ИСТОРИЈЕ НА КАТЕДРИ ЗА БИБЛИОТЕКАРСТВО И ИНФОРМАТИКУ ФИЛОЛОШКОГ ФАКУЛТЕТА У БЕОГРАДУ
}

\section{Сажетак}

Од школске 1991/92, од када непрекидно делује Катедра за библиотекарство и информатику Филолошког факултета Универзитета у Београду, али и пре тога, од формирања Одсека за библиотекарство (1962), преко двогодишњег Смера за библиотекарство и информатику (1981-1991), настава из области историје књиге и библиотека била је незаобилазни и саставни део студијског програма. Данас, на основним студијама Катедре за библиотекарство и информатику, два семестра опште и националне историје књиге и библиотека, заједно са курсевима из архивистике и музеологије, пружају студентима солидну основу за будуће бављење историјским темама. Сама чињеница да су предмети Историја књиге и библиотека 1-2 и Књига и библиотеке код Срба 1-2 обавезни за све студенте, Катедру сврстава у оне малобројне које наставу из ове области не организују као изборну или нуде курсеве из историје књиге, фаворизујүћи је на рачун историје библиотека.

Као и свака друга историја, и историја библиотека повећава човеково разумевање и моћ савладавања окружења. Будући да се њоме, генерално, не баве школовани историчари, на библиотекарским школама је одговорност да негују сам предмет, јачају компетенције студената за историјска истраживања и формирају научно језгро ове дисциплине. За професионалну заједницу библиотекара у Србији уобличавање историје српских библиотека има пресудан значај јер она чини темељ професионалног идентитета и основу за превредновање друштвене мисије и друштвене улоге библиотеке.

Овај аналитичко-синтетички прилог реафирмацији изучавања историје библиотека има за циљ да, у време обележавања 55 година наставе

1 Филолошки факултет, Студентски трг 3, 11000 Београд gordana.stokic.simoncic@gmail.com

2 Назив пројекта: Дигиталне медијске технологије и друштвено-образовне промене. Евиденциони број пројекта: 47020. 
библиотекарства на Универзитету у Београду, подсети на фундаментални значај историјских сагледавања у свим професионалним заједницама.

Кључне речи: библиотекарство, високошколско образовање, наставни програм, историја библиотека, професионални идентитет, Катедра за библиотекарство и информатику, Београд

\section{Увод}

Од школске 1991/92, од када непрекидно делује Катедра за библиотекарство и информатику Филолошког факултета Универзитета у Београду, али и пре тога, од формирања Одсека за библиотекарство (1962), преко двогодишњег Смера за библиотекарство и информатику (1982-1991), настава из области историје књиге и библиотека била је незаобилазни саставни део студијског програма. На домаћим се просторима увек полазило од претпоставке да тек познавање развоја неког феномена омогућава његово пуно разумевање и зато се није приклонило пракси једног броја западноевропских библиотекарских школа које су наставу историје књиге и библиотека релативизовале прогласивши је изборном. Данас, када се у далеко развијенијим библиотечко-информационим системима, попут онога у Скандинавији или САД, јавила забринутост због маргинализације историје библиотека као дисциплине ${ }^{3}$, размишљања предметног наставника на нашим просторима не иду у правцу бити или не бити, него се тичу методологије истраживања и подучавања. Да ли је историја библиотека само то - хронолошки развој институција и њима својствених процеса, или је реч о систему друштвених односа који креира библиотеку у складу са својим ставом према образовању, информисању и култури? Да ли се историја библиотека заиста бави само библиотекама или је то генерички појам који означава укупну област библиотекарства? Колико историја књиге (као уосталом и историја писма) ставља у неравно-

3 Више видети у: Жан-Пјер В. М. Ерибел, „У славу наше прошлости: историјска истраживања, историја библиотека и историографски императив", Гласник Народне библиотеке Србије (2014/2015): 58-73, преузето 1. 3. 2019, https://www.nb.rs/view_ file.php?file_id=4785.

Гордана Стокић Симончић, „Историја библиотека као научна дисциплина“, Гласник Народне библиотеке Србије (2014/2015): 89-90, преузето 1. 3. 2019, https:// www.nb.rs/view_file.php?file_id=4787. 
праван положај историју библиотека? Ко се и из којих побуда бави историјом библиотека? Како се предаје и које су тешкоће студената везане за ову проблематику? Каква је улога библиотекарских школа у неговању кадра за професионална историјска истраживања? Колика је, на националном нивоу, покривеност историјских тема везаних за библиотекарство? Зашто нам је све то уопште важно?

Овај рад настоји да одговори бар на нека од наведених питања, полазећи од претпоставке да су историјска истраживања основ за изградњу идентитета сваке професије, па тако и професионалне заједнице библиотекара у Србији.

\section{Настава историје књиге и библиотека као обавезна}

Данас се, на основним студијама Катедре за библиотекарство и информатику, настава историје књиге и библиотека организује током прва два семестра и то кроз два предмета, који обухватају општу и националну проблематику. Предмет Историја књиге и библиотека заступљен је у обиму од једног двочаса недељно, а сврстан у академскоопштеобразовне. Упоредо, студенти прве године имају и обавезни предмет Књига и библиотеке код Срба као стручно-апликативни, у обиму од два двочаса седмично.

Будући да су наведени предмети део укупног наставног програма на Филолошком факултету, на којем се језик и писмо изучавају по дефиницији, развој писама, суштински везан за изучавање књиге, присутан је у предметима на Катедри за библиотекарство и информатику само у мери неопходној да се разуме повезаност два феномена. И из области историје писама, као и из историје књиге, курикулум Филолошког факултета нуди студентима неколико изборних предмета. Историја књиге и библиотека указује се, међу њима, као потпуно специфичан и за општу културу драгоцен угао посматрања, а за студенте на Катедри као основа за разумевање савремених тенденција у професији. С друге стране, сама чињеница да су предмети Историја књиге и библиотека 1-2 и Књига и библиотеке код Срба 1-2 обавезни за све студенте, Катедру сврстава у оне, сразмерно малобројне у Европи, које наставу из ове области не организују као изборну или нуде курсеве из историје књиге, фаворизујући је на рачун историје библиотека. 
Чини се да је синтагма историја библиотека генерички појам. С обзиром на чињеницу да се користи када су у питању историјска истраживања у библиотекарству, заправо, под њом се подразумева историја библиотечких зграда, установа и организација, али и историја библиотекарства. За историју институција неминовно су везани поједини радни процеси, у хронолошком поретку, биографије појединаца, развој читалачке публике и издаваштва, истраживања корисничких интересовања, технологија штампе, материјали и прибор за писање, тј. физички носиоци информација, због чега је историја библиотека - много више од онога што јој име каже. Енглеске синтагме, library history и history of librarianship, које се често користе алтернативно, једнако су неодређене. С друге стране, историја библиотека обухвата и писање о историји библиотека - начину на који се пише о библиотекама, изворима и методама које се користе приликом историјских истраживања, интерпретацији догађаја и односа. Другим речима, историја библиотека бави се и библиотечком историографијом. ${ }^{4}$

Оно што студенти прве године, наравно, не знају на почетку наставе је да улазе у професионалну заједницу која није изнедрила довољно литературе да покрије области опште и националне историје библиотека. Ситуација са историјом књиге знатно је боља, јер се ово интердисциплинарно поље обогаћује радом историчара књижевности и језика, археографа, конзерватора и кодиколога. Међутим, област историје библиотека далеко је ужа и, чини се, тиче се само библиотекара. Док је инострана литература знатно богатија, на српском језику (а претпоставка је да студенти прве године користе литературу на матерњем језику) њоме се бави тек неколико приручника: 2-3 домаћа, већ застарела, наслова која третирају укупну проблематику ${ }^{5}$ и један број оних који се само делимично баве овим темама или су дело махом хрватских аутора. Расутост текстова, неуједначеност података које доносе, па чак и мали број примерака ових књига представљају објективну тешкоћу у савладавању градива 6 .

4 Стокић Симончић, „Историја библиотека као научна дисциплина“: 89-90.

5 Александар Поповић, Приручник из историје библиотека (Београд:Друштво библиотекара НРС, 1958); Љ. Бацкић-Деспотовић, Историја писма, књиге и библиотека (Београд: Стручна књига, 1980).

6 Звонимир Кулунџић, Како је постала књига (Београд, 1955); Aleksandar Stipčević, Povijest knjige (Zagreb: Nakladni zavod Matice hrvatske, 1985. i 2006); Milan Pelc, Pismo, knjiga, slika: uvod u povijest informacijske kulture (Zagreb: Golden marketing, 2002); Драгутин Фуруновић, Историја и естетика књиге (Београд, 1999); Драгутин Фуруновић, Енциклопедија штампарства (Београд, 1999). 
Оно што студенти прве године, такође, не знају је - општа историја. Генерално лоше знање историје које донесу из средњих школа није довољно да пружи оквир за изучавање историје књиге и библиотека. Предајући годинама овај предмет на Катедри за библиотекарство и информатику Филолошког факултета у Београду, могу са приличном сигурношћу да тврдим да историја није међу омиљеним дисциплинама српске младежи. „Чини се, осим тога, да смо им ми који памтимо више, истраумирани савременом историјом, пренели, ако не нашу конфузију у погледу на историјске догађаје од Другог светског рата наовамо, а оно идеју о узалудности једне области знања коју, ионако, уобличавају - победници. С друге стране, јаке тенденције глобализације имају и онај аспект деловања који бављење историјом готово изједначава са национализмом... Није, дакле, чудо што чак и када знају фактографију не знају контекст - нити су спремни да се њиме много баве."7 Зато настава историје књиге и библиотека не може да буде ређање сувопарних хронолошких факата везаних за библиотеке и библиотекаре, него мора да буде тумачење околности и друштвених односа који доводе до оснивања и напредовања библиотека.

Социолошки оквир би, при томе, требало да одреди предметни наставник и да га непрестано супротставља дубоко увреженим ставовима о инертности библиотека као институција. Према нашем схватању, оквир у који би требало поставити развој библиотека чине економска моћ оснивача и ниво демократичности односа у одређеној средини. С једне стране, библиотеке настају онда када економска моћ одређеног друштва постане толика да омогућава њихово оснивање и издржавање. С друге стране, предуслов за напредовање библиотека су демократски односи у друштву, а начин образовања, односно врста знања, оспособљености, квалификација и вештина које се сматрају друштвено пожељним, директно утиче на њихов развој. Што је шире замишљена структура образовања, што су веће могућности појединаца да постану део те структуре, а затим, што су им доступнији извори знања и информисања, то су и библиотеке развијеније. Историја библиотека открива да су оне такве какав је и однос одређене заједнице према знању и, још прецизније, према одређеним нивоима и врстама знања. ${ }^{8}$ Најшире дефинисана улога

7 Гордана Стокић Симончић, „У трагању за историјом“, Читалиште: научни часопис за теорију и праксу библиотекарства бр. 18 (мај 2011): 1.

8 Гордана Стокић Симончић, „Увод или чему нас учи историја библиотека“, у Библиотека кроз време: Прилози општој историји библиотека до 16. века, Гордана Стокић Симончић прир. (Панчево: Градска библиотека; Београд: Филолошки факултет Универзитета, 2017), 8. 
библиотека - да повезују људе и забележено знање - директно зависи од стратегијских циљева које једно друштво себи поставља у домену образовања, информисања и културног развоја својих чланова.

\section{Српске библиотеке траже своју историју}

У културној историји Срба историја библиотека још није нашла заслужено место, а не може га ни наћи овако непотпуна и недоследна каква је. Историјом српских библиотека бави се сразмерно мали број библиотекара и то са променљивим успехом, а изван струке готово нико. То није специфичност нашег библиотекарства, али је звоно за узбуну у тренутку кризе професионалног идентитета и све интензивнијег утицаја политике на професионалну сферу.

Корени савременог српског библиотекарства налазе се у 18. веку који је Србима донео прве школске и специјалне библиотеке, а уз најстарије - манастирске, још читав низ религијских библиотека: епархијске, митрополијске, парохијске. У 19. веку јачале су приватне и школске библиотеке, али је он изнедрио и националну библиотеку, читалишта и јавне библиотеке као свој највиши домет. Такође и прве законе који се односе на библиотечку делатност, обавезни примерак, именовање првог државног библиотекара... Двадесети век био је време стандардизације пословања, интернационализације делатности, почетка аутоматизације, али и век великих ломова за српске библиотеке: време растурања и уништавања библиотека у ратовима, време цензурисања књига и време изолације. ${ }^{9}$

Три века развоја библиотека и готово један век дуги покушаји да се делатност библиотекара етаблира као професија, нису уродили заједничким памћењем.

„Да би нека друштвена група имала свој колективни идентитет, потребно је да постоји заједничко тумачење догађаја и доживљеног који су током времена утицали на обликовање те заједнице“ ${ }^{\prime 10}$.

9 Гордана Стокић Симончић и Жељко Вучковић, Библиотеке и идентитет: пролегомена за историју модерног српског библиотекарства (Панчево: Градска библиотека; Нови Сад: Филозофски факултет, 2012).

10 Џон Тош, У трагању за историјом: Циљеви, методи и нови правци у проучавању савремене историје (Београд: Clio, 2008), 23. 
Овај став историчара Џона Тоша, према коме заједничко памћење представља предуслов за постојање колективног идентитета, може објаснити бројне мањкавости у вези са позиционирањем библиотека у савременом српском друштву. Између осталих и оне који се баве историјом домаћих библиотека. Данас не знамо, на пример, ко је први српски библиотекар и на основу којих критеријума бисмо га првим библиотекаром могли означити; тек смо утврдили колико је јавних библиотека радило у Србији између два светска рата; недоследност у тумачењу односа читалишта и јавних библиотека још увек чини године оснивања појединих јавних библиотека у најмању руку проблематичним; немамо јасну представу о укупним дометима српског библиотекарства после Другог светског рата, нарочито о, по професионалним дометима, фасцинантном периоду 1960-1990. године; о професионалном удружењу, Библиотекарском друштву Србије, недовољно знамо па му ове године обележавамо 70-годишњицу, а могли бисмо да обележимо 88-годишњицу; немамо лексикон знаменитих библиотекара; не трудимо се да оповргнемо страшне оптужбе које нас терете да смо народ који се, у последњој деценији 20. века, вандалски односио према туђој књизи и библиотекама. ${ }^{11}$

Све ово временски се подудара са писањем нове историје балканских народа, при чему су библиотеке моћно средство за манипулацију. У то је могуће уверити се и прегледањем веб-страница националних библиотека у окружењу, на којима се уопште не помиње 70 година рада у јединственом југословенском библиотечком систему. Парадигматичан је и пример Друштва југословенских библиотекара ДЈБ које је почело са радом 1931. године, након што су конституисане његове три секције: Београдска (4. априла), Загребачка (8. априла) и Љубљанска (13. јуна), а обуставило активности крајем 1938, пошто је Загребачка секција изнела предлог да се, уместо ДЈБ, формирају три засебна друштва, а чланови Главне управе из Београда, у знак протеста, поднели оставке. Осам година деловања првог професионалног библиотекарског удружења на југословенским просторима потом је готово пало у заборав, а касније основана друштва, велика већина некадашњих чланова, као и историчари библиотекарства, прећуткивали су, углавном из политичких разлога, његово постојање.

11 Стокић Симончић и Вучковић, Библиотеке и идентитет: пролегомена за историју модерног српског библиотекарства. 
Данас се на веб-страници Хрватског књижничарског друштва ${ }^{12}$ не помиње Друштво југословенских библиотекара нити његова Загребачка секција. Као година оснивања струковног удружења наводи се 1940, када су практично исти они чланови који су од оснивања ДБЈ били најактивнији представници Загребачке секције - др Јосип Бадалић (1888-1985), Матко Ројнић (1908-1981), Ева Верона (1905-1996), Марко Орешковић (1909-2005), др Елза Кучера (1883-1972) - основали самостално Друштво. Они су, затим, након Другог светског рата, активно учествовали у стварању и раду Друштва библиотекара Хрватске, основаног 25. новембра $1948 .{ }^{13}$ И док хрватски веб-сајт потпуно прећуткује ДБ, словеначки истиче само штуру информацију о томе како су се словеначки библиотекари најпре учлањивали у Аустријско библиотекарско удружење, а да је 1931. у Загребу основано Друштво југословенских библиотекара те да је љубљанска секција у њему била представљена иницијално са шест, а укупно са 10 чланова, који су, додуше, наведени поименце! ${ }^{14}$

Утврђивање историјских чињеница суштинско је питање сваке историје, па и историје библиотека. Онда када нека професионална групација из било ког разлога (фаворизовања библиотекарске праксе, утилитарности професије или политичких интереса) одустане од чињеница везаних за сопствени развој, лако се одриче од историјских истраживања уопште. Насупрот томе, истрајавање на хронологији догађаја, разумевању односа и оквира догађања, узрочно-последичним везама, не само да јача компетентност појединаца, него јача самосвест библиотекарске заједнице у целини. Тако је и вишедеценијско истрајавање Катедре за библиотекарство и информатику Филолошког факултета у Београду на историји књиге и, посебно, библиотека дало значајне резултате. Примера ради, комплетан историјат јавних библи-

12 Hrvatsko knjižničarsko društvo, „Povijest”, preuzeto 15. 1. 2017, http://www. hkdrustvo.hr/hr/o_nama/povijest/. У том тексту се помиње један пожутели папир, из чега се може закључити да они друге грађе и немају. У Београду се налази и акт на основу којег се може говорити о тачном датуму оснивања, а који се не наводи на вебстраници. Др Јосип Бадалић, Матко Ројнић, Ева Верона, Марко Орешковић, др Елза Кучера потписали су приступнице током марта и априла 1940.

13 Гордана Стокић Симончић, „Друштво југословенских библиотекара и Библиотекарско друштво Србије: континуитет професионалног удруживања“, читалиште: научни часопис за теорију и праксу библиотекарства бр. 31 (новембар 2017): 56 61, doi: 10.19090/cit.2017.31.56-61.

14 Zveza bibliotekarskih društev Slovenije, „Zgodovina“, preuzeto 15. 1. 2017, http:// www.zbds-zveza.si/?q=node1/50. 
отека успостављен је серијом израђених докторских дисертација ${ }^{15}$, превреднована је улога манастирских библиотека у развоју српске културе ${ }^{16}$, исправљају се заблуде и разрешавају непознанице везане за одређене историјске личности или епохе. Изучавани на нивоу докторских, односно магистарских студија, сви ови феномени су везани за „историјску секцију“ Катедре за библиотекарство и информатику Филолошког факултета, а наставак историјских истраживања омогућиће да кроз један број дисертација - дођемо до потпуно уобличене и поуздане историје библиотека код Срба. Тек на тој платформи биће могуће градити колективни идентитет библиотекара у Србији.

\section{Закључак}

Будући да се историјом библиотека генерално не баве школовани историчари, на библиотекарским је школама одговорност да негују сам предмет, јачају компетенције студената за историјска истраживања и формирају научно језгро ове дисциплине. Два семестра опште и националне историје књиге и библиотека, заједно са курсевима из архивистике и музеологије, пружају студентима Катедре за библиотекарство и информатику у Београду солидну основу за будуће бављење историјским темама. Историја библиотека као дисциплина сазрева у националним оквирима једнако као и у међународним, а питања њеног обухвата, аутономности и компетенција истраживача, требало би посматрати као саставни део тог процеса.

У оквиру савременог поља културе на националном нивоу, библиотечко-информациона делатност је далеко најбоље организована, а на то утиче и импетив сарадње, повезивања и умрежавања који је интернационални и којега јасно заступају кровне међународне

15 Од читалишта у Србији у 19. веку (Десанка Стаматовић) и теоријскометодолошких сагледавања феномена јавности у библиотекарском контексту (Жељко Вучковић), преко историјата јавне библиотеке у Крагујевцу (Мила Стефановић), јавних библиотека у Србији 1901-1918. године (Бранка Драгосавац) и између два светска рата (Биљана Ђурашиновић) прати се линија историјских синтеза које воде ка изчавању савременог српског библиотекарства. Претходила су им, свакако, бројна и разноврсна појединачна истраживања која морају бити основа и која, превреднована, омогућавају научне синтезе.

16 Ж. Војновић, „Манастирске библиотеке на подручју карловачке митрополије у 18. веку“ (докторска дис., Филолошки факултет Универзитета у Београду, 2018). 
библиотекарске организације. Време је да библиотеке - најстарије културне институције код Срба-путем научнихисторијскихистраживања, добију поуздану и неупитну историју, а тиме и заслужено место како на националном тако и на међународном плану.

\section{Литература и извори:}

Бацкић-Деспотовић, Љ. Историја писма, књиге и библиотека. Београд: Стручна књига, 1980.

Војновић, Ж. „Манастирске библиотеке на подручју карловачке митрополије у 18. веку“. Докторска дис., Филолошки факултет Универзитета у Београду, 2018.

Ерибел, Жан-Пјер В. М. „У славу наше прошлости: историјска истраживања, историја библиотека и историографски императив“. Гласник Народне библиотеке Србије (2014/2015): 58-73. Преузето 1. 3. 2019. https://www.nb.rs/view_file. php?file_id $=4785$.

Zveza bibliotekarskih društev Slovenije. „Zgodovina“. Preuzeto 15. 1. 2017. http://www. zbds-zveza.si/?q=node1/50.

Кулунџић, Звонимир. Како је постала књига. Београд, 1955.

Pelc, Milan. Pismo, knjiga, slika: uvod u povijest informacijske kulture. Zagreb: Golden marketing, 2002.

Поповић, Александар. Приручник из историје библиотека. Београд: Друштво библиотекара НPC, 1958.

Stipčević, Aleksandar. Povijest knjige. Zagreb: Nakladni zavod Matice hrvatske, 1985. i 2006.

Стокић Симончић, Гордана. „Друштво југословенских библиотекара и Библиотекарско друштво Србије: континуитет професионалног удруживања“. Читалиште: научни часопис за теорију и праксу библиотекарства бр. 31 (новембар 2017): 56-61. doi: 10.19090/cit.2017.31.56-61.

Стокић Симончић, Гордана и Жељко Вучковић. Библиотеке и идентитет: пролегомена за историју модерног српског библиотекарства. Панчево: Градска библиотека; Нови Сад: Филозофски факултет, 2012.

Стокић Симончић, Гордана. „Историја библиотека као научна дисциплина“. Гласник Народне библиотеке Србије (2014/2015): 89-90. Преузето 1. 3. 2019. https:// www.nb.rs/view_file.php?file_id $=4787$.

Стокић Симончић, Гордана. „Увод или чему нас учи историја библиотека“. У Библиотека кроз време: Прилози општој историји библиотека до 16. века. Гордана Стокић Симончић, прир., 7-9. Панчево: Градска библиотека; Београд: Филолошки факултет Универзитета, 2017.

Стокић Симончић, Гордана. „У трагању за историјом“. Читалиште: научни часопис за теорију и праксу библиотекарства бр. 18 (мај 2011): 1-2.

Тош, Џон. У трагању за историјом: Циљеви, методи и нови правци у проучавању савремене историје. Београд: Clio, 2008.

Фуруновић, Драгутин. Енциклопедија штампарства. Београд, 1999.

Фуруновић, Драгутин. Историја и естетика књиге. Београд, 1999.

Hrvatsko knjižničarsko društvo. „Povijest”. Preuzeto 15. 1. 2017. http://www.hkdrustvo.hr/ hr/o_nama/povijest/. 


\section{Prof. Gordana Stokić Simončić, PhD}

\section{HISTORY AS A TEACHING SUBJECT AT THE DEPARTMENT OF LIBRARY AND INFORMATION SCIENCE}

\section{Summary}

Since the school year 1991/92, when actually operating Department of Library and Information Science, Faculty of Philology, University of Belgrade, started and even before that, since the establishment of the Department of Library Science (1962), and the two-year course for Library and Information Science (1981-1991), teaching history of the book and libraries was an essential and integral part of the study program. Today, the basic studies at the Department of Library and Information Science include two semesters of general and national history of the book and libraries, and together with courses in archival science and museology, provide students with a solid foundation for future dealing with historical issues. The mere fact that the subjects of the general book and libraries history, and national history of the book and libraries are compulsory for all students, ranks the Department among the few ones that do not organized the subjects as an elective or offer courses in the book history, favoring it in relation to library history.

Like every other history, library history increases man's understanding and mastering the power of the environment. Since it is generally not dealing with trained historians, library schools have a responsibility to nurture the object itself, strengthen students' competence for historical research and form the core of this scientific discipline. For professional community of librarians in Serbia shaping the history of Serbian libraries is crucial as it forms the basis of professional identity and the basis for a reevaluation of the social mission and social role of libraries.

At the time when we celebrate 55 years of teaching librarianship at the University of Belgrade, this syntetical contribution to reaffirmation of studying library history aims to remind to the fundamental importance of historical observation in all professional communities.

Key words: Library and information science, higher education, curriculum, library history, professional identity, Department of Library and Information, Paculty of Philolgy, University of Belgrade. 